defines their prevalence, and sets the aims and objectives of mental health services for this age group, giving helpful guidelines on dealing with the knotty problems of quality assurance, audit, monitoring contract compliance, and meeting users' needs. ${ }^{7}$ It should be studied not only by purchasers but also by providers of services in the new NHS, including managers of services for mental health and children in trust hospitals.

Despite the high prevalence of mental health problems among children-about 1 in 10 children have disorders of emotions or conduct or other psychiatric disorders that interfere with development and functioning-child and adolescent psychiatry has always been a cinderella specialty. If the government seriously wants to reduce the prevalence of mental illness resulting in suicide it must encourage purchasers to use the guidelines produced by Action for the Sick Child to ensure the provision of appropriate services. By redistributing the derisory amount currently spent on child mental health it will not achieve this aim.

DORA BLACK

Consultant Child and Adolescent Psychiatrist,

Royal Free Hospital,

London NW3 2RG

1 Secretary of State for Health. The health of the nation. London: HMSO, 1991. (Cm 1986.)

2 Brown G, Harris T. The social origins of depression. London: Tavistock, 1978.

3 Goodyer IM. Life experiences, development and childhood psychopathology. Chichester: Wiley, 1990.

4 Parkes CM. Bereavement: studies of grief in adult life. Harmondsworth: Penguin, 1986.

5 Black D, Urbanowicz MA. Family intervention with bereaved children. $f$ Child Psychol Psychiatry 1987;28:467-76.

6 Black D, Urbanowicz MA. Bereaved children-family intervention. In: Stevenson JE, ed. Recent research in developmental psychopathology. Oxford: Pergammon, 1985;179-87.

$7 \mathrm{Kurtz}$ Z. With health in mind. London: Action for Sick Children, 1992.

8 Taylor EA, Stansfeld SA. Children who poison themselves. I. A clinical comparison with psychiatric controls. Brf Psychiatry 1984;145:127-35.

Otto U. Suicidal acts by children and adolescents: a follow-up study. Acta Psychiat Scand 1972;233[suppl]:5-23.

10 Black D. Consultant manpower in child psychiatry. Psychiatric Bulletin 1989;13:32-5.

11 Drabble M. Someone to watch over them. Times 1992 July 8:C5.

\title{
"Without work all life goes rotten"
}

\section{Unemployment kills, ruins health, and destroys families}

Nothing to do with time; nothing to spend; nothing to do tomorrow nor the day after; nothing to wear; can't get married. A living corpse; a unit of the spectral army of the three million lost men.

\section{WALTER GREENWOOD}

Politicians may not understand what unemployment feels like from the inside, but writers do. Albert Camus said that "Without work all life goes rotten"; Walter Greenwood produced the quote above in his book Love on the Dole; and George Orwell described the miseries of unemployment in The Road to Wigan Pier, ${ }^{2}$ observing that "It is only when you lodge in streets where nobody has a job [and] where gettting a job seems about as probable as owning an aeroplane ... that you begin to understand the changes that are being worked in our society." The week when 30000 British miners learnt that they would lose their jobs and when unemployment reached 2.84 million seems like the right time to remind doctors and politicians of just how much we know about how unemployment damages health. ${ }^{34}$

Many of those miners who will lose their jobs will die prematurely as a result. Unemployment raises the chance that a man will die in the next decade by about a third, and for those in middle age - with the biggest commitments - the chance doubles. ${ }^{56}$ The men are most likely to die from suicide, cancer, and accidents and violence. Their wives will also face a higher chance of dying and so will their children and unborn babies. ${ }^{3}$ Separation, divorce, and family violence are also linked with unemployment. ${ }^{37}$ Exactly how unemployment kills is unclear, but it is through a combination of poverty, stress, adoption of unhealthy behaviours, and the devastating effect on mental health. And it is not only miners who are affected: many people in the south east of England are experiencing unemployment for the first time in cultures that are less familiar with the ravages of joblessness.

The physical health of the unemployed tends to deteriorate, and they are likely to visit their general practitioners more often - particularly with chronic cardiovascular conditions. ${ }^{89}$ But it is mental health that is most harmed by unemployment. The unemployed experience anxiety, depression, neurotic disorders, poor self esteem, and disturbed sleep patterns, and they are more likely than the employed not only to kill themselves but also to injure themselves deliberately. ${ }^{4}$ The psychological damage stems mainly from loss-of status, purpose, social contacts, income, and a sense of belonging and mattering. Unemployment also brings stigma, humiliation, and a reduced scope for making decisions. Marie Jahoda and her colleagues described in their classic studies of Marienthal in the 1930s how the Austrian town was frozen by mass unemployment into apathy, poverty, and pointlessness, ${ }^{10}$ and Adrian Sinfield has observed that "Prolonged unemployment is for most people a profoundly corrosive experience, undermining personality and atrophying work possibilities."

For many of those in the abandoned mining communities it will be impossible to find new jobs, which is tragic as reemployment - in a job of equal value and status - is the only certain "cure" for the misery of unemployment. Research into ways of ameliorating the harmful effects of unemployment is much less developed than research into whether unemployment harms and how, but retraining, counselling, advice on benefits, education, careers advice, and social action may all help. Doctors can help with these activities, but politicians have greater scope for action. So far, however, they have shown little sign of understanding the extent of the misery that is being created. For instance, the precipitous way in which some miners are being thrown out of jobs held for 20 30 years with only two days' warning is likely to be extremely damaging. We must hope that those ministers particularly responsible for health can make their voices heard at a Cabinet table understandably preoccupied with a collapsing economy. After all, isn't that the point of The Health of the Nation? Or will it become The Health of Two Nations?

RICHARD SMITH Editor, $B M \mathcal{F}$

1 Greenwood W. Love on the dole. Harmondsworth: Penguin, 1969. (First published 1933).

2 Orwell G. The road to Wigan pier. London: Victor Gollancz, 1937.

3 Smith R. Unemployment and health: an opportunity and a disaster. Oxford: Oxford University Press, 1987.

4 Warr PB. Work, unemployment, and mental health. Oxford: Clarendon Press, 1987.

5 Moser KA, Fox AJ, Jones DR, Goldblatt PO. Unemployment and mortality: further evidence from the OPCS longitudinal study 1971-81. Lancet 1986;i:365-6.

6 Moser KA, Goldblatt PO, Fox AJ, Jones DR. Unemployment and mortality: comparison of the 1971 and 1981 longitudinal study census samples. $B M \mathcal{F} 1987 ; 294: 86-90$.

7 Popay J. Unemployment and the family. London: Unemployment Alliance, 1984.

8 Beale N, Nethercott S. Job loss and family morbidity: a study of factory closure. $f$ R Coll Gen Pract 1985;280:200-2.

Beale N, Nethercott S. The nature of unemployment morbidity. 2. Description. $f R$ Cell Gen Pract 1988;38:390-4.

10 Jahoda M, Lazarsfield PF, Zeisl H. Marienthal: the sociography of an unemployed community. London: Tavistock, Publications. 1972. (German edition published 1933).

11 Sinfield A. What unemployment means. Oxford: Martin Robertson, 1981. 